\title{
https://doi.org/10.46813/2021-131-136 \\ PLASMA-CATALYTIC SYSTEM WITH NARROW-APERTURE ROTATING GLIDING DISCHARGE
}

\author{
O.A. Nedybaliuk, P.V. Tyshchuk, T.A. Tereshchenko, I.I. Fedirchyk \\ Taras Shevchenko National University of Kyiv, Kyiv, Ukraine
}

\section{E-mail: oanedybaliuk@gmail.com}

The article presents the results of the investigation of the rotating gliding discharge with the narrow aperture in the airflow. The photographs of the rotating gliding discharge with the narrow aperture were matched with its voltage oscillograms. Photographs were used to determine the maximum length of the discharge channel and its dependence on the airflow $G_{d}$ into the discharge chamber. Voltage oscillograms were used to determine the difference between the maximum and minimum discharge voltage $\Delta U=U_{\max }-U_{\min }$. The dependence of the electric field in the positive column on the airflow $G_{d}$ into the discharge chamber was plotted. Optical emission spectra of the plasma of the rotating gliding discharge with a narrow aperture were captured and used to determine the distribution of the vibrational $T_{v}$ and rotational $T_{r}$ temperatures along the length of the plasma torch inside the reaction chamber.

PACS: 52.50.Dg, 52.80.-s

\section{INTRODUCTION}

To achieve the goals of sustainable development, humanity needs to shift as much of its production as possible towards the use of renewable raw materials [1]. The biggest and most important for sustainable development is the replacement of fossil hydrocarbons with renewable feedstock based on biomass. However, the technologies for the effective conversion of the renewable raw materials into the targeted products are still severely underdeveloped [2]. Traditional reforming technologies, such as thermochemical and catalytic reforming, were developed and optimized based on fossil hydrocarbon raw materials, which have a less complex and varied composition compared to the renewable feedstock.

Plasma is a chemically active environment with a high concentration of active particles (ions, electrons, radicals, excited species, etc.), which can stimulate and support the long-chain chemical reactions. This interaction is known in plasma chemistry as plasma catalysis [3]. The use of plasma catalysis instead of the traditional catalysts removes the problems caused by the catalyst poisoning and provides additional advantages, such as short reaction time and a high degree of control over the process.

Plasma-catalytic reforming of hydrocarbons is one of the most energy-efficient processes that convert hydrocarbons into synthesis gas, especially in comparison with the conventional plasma reforming, as shown in [4]. The plasma sources that were used during the plasma-catalytic reforming include rotating gliding discharges with wide [5, 6] and narrow [7, 8] aperture. The presence of the plasma gas flow, which is transverse to the discharge channel, allows rotating gliding discharges to produce nonthermal plasma. However, the plasma of the rotating gliding discharges with the narrow aperture is studied insufficiently.

This work is focused on the investigation of the rotating gliding discharge with the narrow aperture, which is used for the plasma-catalytic reforming of the hydrocarbons into the synthesis gas. The knowledge of the electric field $\mathrm{E}$, rotational $\mathrm{T}_{\mathrm{r}}$ temperature, vibrational $\mathrm{T}_{\mathrm{v}}$ temperature, and the flows of the reactant allows conducting numerical modeling of the chemical kinetics during the plasma-catalytic reforming. The numerical modeling will provide an opportunity to determine the optimal operation modes aimed at the maximum yield of targeted conversion products.

\section{EXPERIMENTAL SET-UP AND METHODOLOGY}

Fig. 1 shows the scheme of the plasma-catalytic system with narrow-aperture rotating gliding discharge.

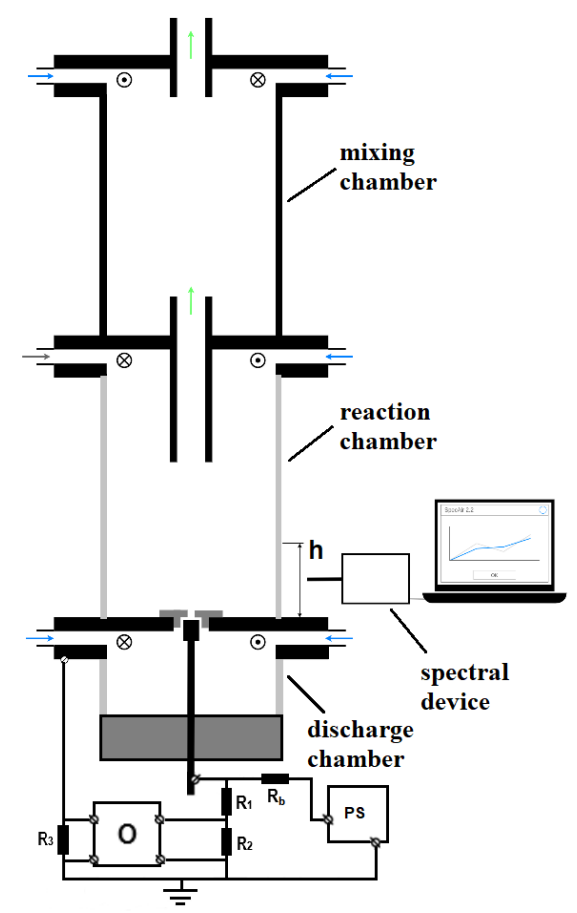

Fig. 1. Scheme of a plasma-catalytic system with narrow-aperture rotating gliding discharge 
The plasma-catalytic system with the narrowaperture rotating gliding discharge comprises the three cylindrical chambers, closed from both sides with flanges: the discharge chamber, the reaction chamber, and the mixing chamber. The wall of the discharge chamber is made of quartz and shaped like a cylinder $20 \mathrm{~mm}$ high and $38 \mathrm{~mm}$ in diameter. The top and bottom of the discharge chamber are sealed with the flanges. The bottom flange of the discharge chamber is made of PA-6 block, and the top flange was made of stainless steel. A cylindrical stainless-steel electrode is fixed to the bottom flange of the discharge chamber. The top flange of the discharge chamber has a $4 \mathrm{~mm}$ hole and serves as the second electrode. The plasma gas is introduced into the discharge chamber perpendicularly to the quartz wall and forms a vortex flow. Plasma gas flows toward the $4 \mathrm{~mm}$ hole in the top metal flange and enters the reaction chamber.

The wall of the reaction chamber is made of quartz and has a cylinder shape $100 \mathrm{~mm}$ high and $38 \mathrm{~mm}$ in diameter. The reaction chamber is sealed from top and bottom with stainless-steel flanges. The bottom flange is shared with the discharge chamber, and the top flange is shared with the mixing chamber. The mixture of the hydrocarbon and part of the air is introduced into the reaction chamber through the holes in the top flange perpendicular to the quartz wall of the reaction chamber. The flow of the hydrocarbon-air mixture moves downward, into the area where the active particles are introduced from the discharge chamber, and exits along the axis into the mixing chamber, which creates a reverse vortex flow.

The wall of the mixing chamber is made of stainless steel and has a cylinder shape $100 \mathrm{~mm}$ high and $38 \mathrm{~mm}$ in diameter. The chamber is sealed from top and bottom with stainless-steel flanges. The flow of gas in the chamber is introduced tangentially to the chamber wall and then mixed with the gas flowing from the reaction chamber.

A scheme in Fig. 2 describes the movement of the plasma gas near the electrodes. The plasma channel formed between the metal electrodes has a changing length due to the influence of the gas flow. One end of the discharge channel (1) was at the center of the cylindrical electrode (2), while the other end was moving along the top metal flange (3). In the area near the symmetry axis, the flow of the plasma gas is directed alongside the discharge channel while it passes transversely to the discharge channel in other areas.

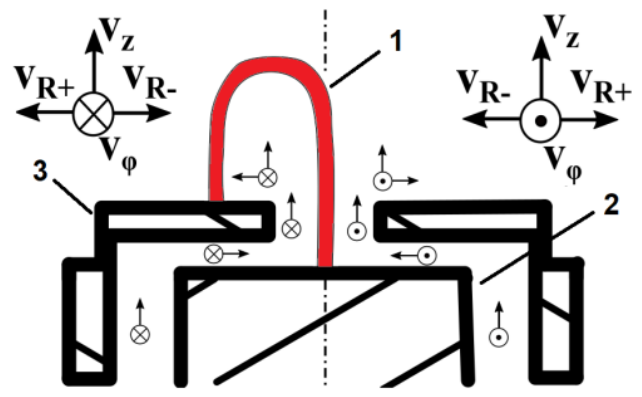

Fig. 2. Schematic representation of plasma gas flow near electrodes: 1 -discharge channel; 2 -cylindrical electrode (anode); 3 - top metal flange (cathode)
The narrow-aperture rotating gliding discharge was powered by a BP-100 power supply (PS) via the $33 \mathrm{k} \Omega$ ballast resistance $\left(R_{b}\right)$, which provided a discharge gap with a voltage of up to $7 \mathrm{kV}$. The voltage and current oscillograms were measured by MTX 1054B oscilloscope $(\mathrm{O})$ with the voltage divider made of resistances $R_{1}$ and $R_{2}\left(R_{1}: R_{2}=1000: 1\right)$ and a $10 \Omega$ measuring resistance $R_{3}$.

The air was supplied by a Fiac Cosmos compressor. The total airflow was divided between the discharge chamber and the reaction chamber. The airflow into each chamber was controlled using Dwyer RMA-22 SSV and Dwyer RMA-23 SSV rotameters.

The optical emission spectra of the plasma were captured using a system comprising a Solar TII S-1502-3648 USB spectral device and an optic fiber, which was secured at a distance $h$ from the bottom of the reaction chamber. Obtained optical emission spectra were used to determine the rotational and vibrational temperatures of the $\mathrm{N}_{2}$ molecules inside the reaction chamber. The temperatures were determined via the comparison between the experimental optical emission spectra and spectra modeled using SpecAir 2.2 software [9]. Both experimental and modeled spectra were normalized based on the maximum intensity near the $380 \mathrm{~nm}$ wavelength.

The change of the discharge channel length $\Delta \mathrm{L}$ was obtained by using the images of the rotating gliding discharge with a narrow aperture captured by a video camera at $125 \mu$ s exposure. This was done by choosing the images with the longest discharge channel $\left(\mathrm{L}_{\max }\right)$ that was arranged in the same plane as an image (perpendicular to the camera's line of sight). The change of the discharge channel length was calculated as a difference between the maximum $\left(\mathrm{L}_{\max }\right.$, which includes the visible part of the channel and the part hidden by the flange) and the minimum $\left(\mathrm{L}_{\min }\right.$, the distance between the electrodes) length of the discharge channel $\left(\Delta \mathrm{L}=\mathrm{L}_{\max }-\mathrm{L}_{\min }\right)$.

The voltage oscillograms were used to calculate the difference between the maximum $\left(\mathrm{U}_{\max }\right)$ and minimum $\left(\mathrm{U}_{\min }\right)$ discharge voltage $\Delta \mathrm{U}=\mathrm{U}_{\max }-\mathrm{U}_{\min }$. The electric field $\mathrm{E}$ in a positive column of the discharge was obtained by dividing the voltage difference $\Delta U$ by the change of the discharge channel length $\Delta \mathrm{L}$.

\section{RESULTS AND DISCUSSION}

Fig. 3 shows the typical emission spectrum of the plasma inside the reaction chamber. The emission spectrum contains the bands of the second positive system of nitrogen $\mathrm{N}_{2} \quad\left(C \Pi_{u} \rightarrow B \Pi_{g}\right.$ transition) and hydroxyl $\mathrm{OH}\left(\mathrm{A}^{2} \Sigma^{+} \rightarrow \mathrm{X}^{2} \Pi\right.$ transition). Comparison of the plasma emission spectra of the narrow-aperture rotating gliding discharge (see Fig. 3) with the spectra of the wide-aperture rotating gliding discharge [10] show that the $\mathrm{N}_{2}$ bands have a higher intensity than $\mathrm{OH}$ bands. This can indicate lower rotational temperature $T_{r}$ of the rotating gliding discharge with the narrow aperture.

Rotational $T_{r}$ and vibrational $T_{v}$ temperatures of the $\mathrm{N}_{2}$ molecules were determined using a comparison between the experimentally measured optical emission 
spectra of the plasma of the rotating gliding discharge with the narrow aperture and the spectra modeled using Spec Air 2.2 software [9]. Fig. 4 presents the dependences of the vibrational $\mathrm{T}_{\mathrm{v}}\left(\mathrm{N}_{2}\right)$ and rotational $\mathrm{T}_{\mathrm{r}}\left(\mathrm{N}_{2}\right)$ temperatures on the height $\mathrm{h}$ over the electrode (cathode) surface.

Figs. 5 and 6 show the typical voltage (see Fig. 5) and current (see Fig. 6) oscillograms of the rotating gliding discharge with the narrow aperture for the $\mathrm{G}_{\mathrm{d}}=10 \mathrm{l} \cdot \mathrm{min}^{-1}$ flow of the air into the discharge chamber.

The measured current and voltage oscillograms were used to build the time dependence of the instantaneous discharge power. Fig. 7 shows the typical time dependence of the instantaneous power of the narrowaperture discharge.

The discharge current is regulated by changing the transformer voltage using a constant ballast resistance of $33 \mathrm{k} \Omega$. This means that the angle of the power supply load line does not change with the increase of the voltage, instead, the load line shifts up toward higher voltages. The discharge disappears when the voltagecurrent characteristic of the discharge is located over the power supply load line, and they do not intersect each other.

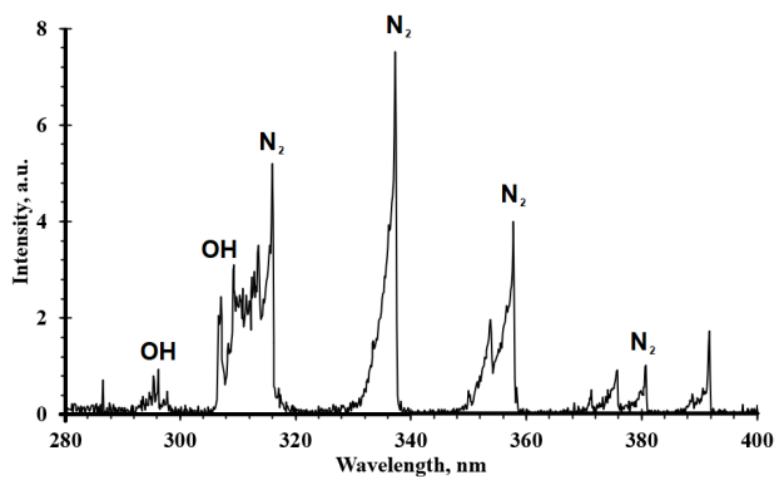

Fig. 3. The typical emission spectrum of plasma inside reaction chamber produced by rotating gliding discharge with narrow aperture: height $h=0 \mathrm{~mm}$; airflow into discharge chamber $G_{d}=10 \mathrm{l} \cdot \mathrm{min}^{-1}$

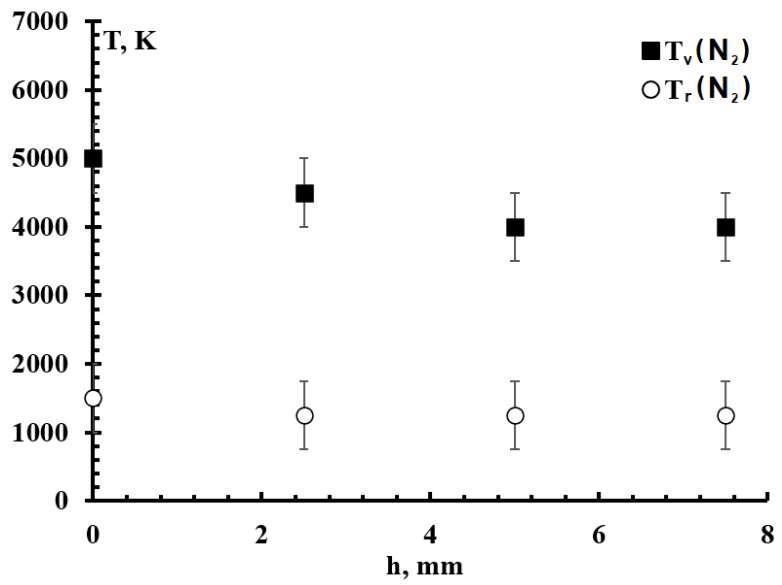

Fig. 4. Dependences of vibrational $T_{v}$ and rotational $T_{r}$ temperatures determined using bands of second positive systems of nitrogen $\mathrm{N}_{2}\left(C \Pi_{u} \rightarrow B \Pi_{g}\right.$ transition) on distance $h$ above electrode (cathode) surface

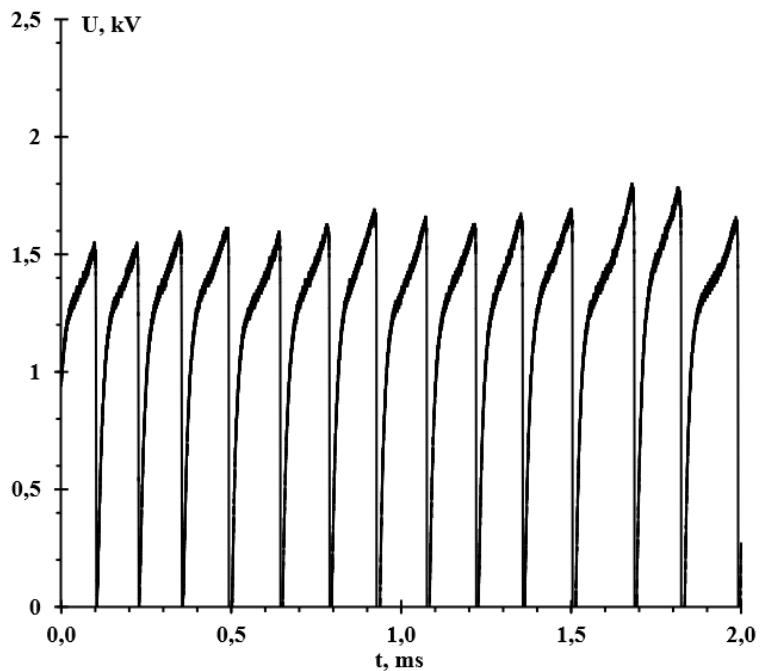

Fig. 5. Typical voltage oscillogram of rotating gliding discharge with narrow aperture: airflow into discharge chamber is $G_{d}=10 \mathrm{l} \cdot \mathrm{min}^{-1}$

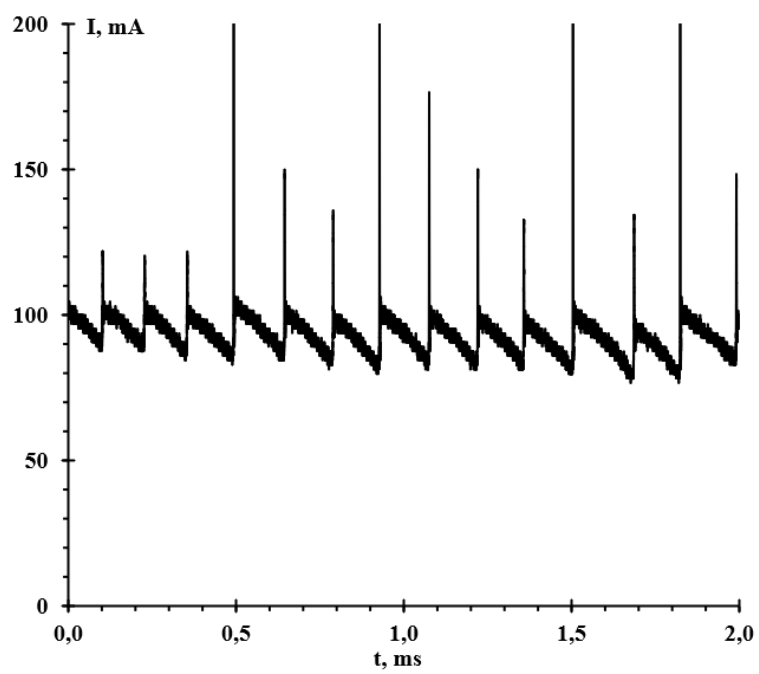

Fig. 6. The typical current oscillogram of rotating gliding discharge with narrow aperture: airflow into discharge chamber is $G_{d}=10 \mathrm{l} \cdot \mathrm{min}^{-1}$

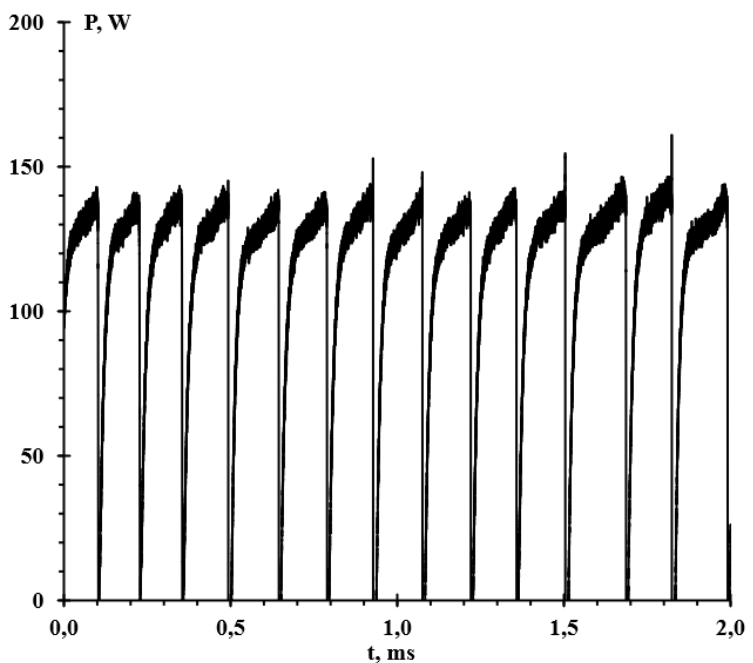

Fig. 7. The typical time dependence of instantaneous power of narrow-aperture discharge: airflow into discharge chamber is $G_{d}=10 \mathrm{l} \cdot \mathrm{min}^{-1}$ 
Figs. 8, 9 shows the load line of the BP-100 PS, which outputs $7 \mathrm{kV}$ voltage with $33 \mathrm{k} \Omega$ ballast resistance, and the voltage-current characteristic of the discharge. The angle of the load line corresponds to the experimental value and the shape of the voltage-current characteristics is apparent. Fig. 8 presents the shift of the load line from top to bottom relative to the voltagecurrent characteristic of the discharge, which took place with the decrease of the power source output voltage. The length of the discharge channel stayed the same during the voltage decrease. The intersection between the load line and the voltage-current characteristic of the discharge determines the operating point. In the case of two intersections, the operating point is the one with lower voltage. With the decrease of the PS output voltage, the load line shifts downward and the operating point moves left towards the lower current. In this way, the current can be regulated without changing the ballast resistance. However, if the load line (see Fig. 8) drops below the voltage-current characteristic and will not have an intersection with it, the discharge will die out and the current will stop flowing.

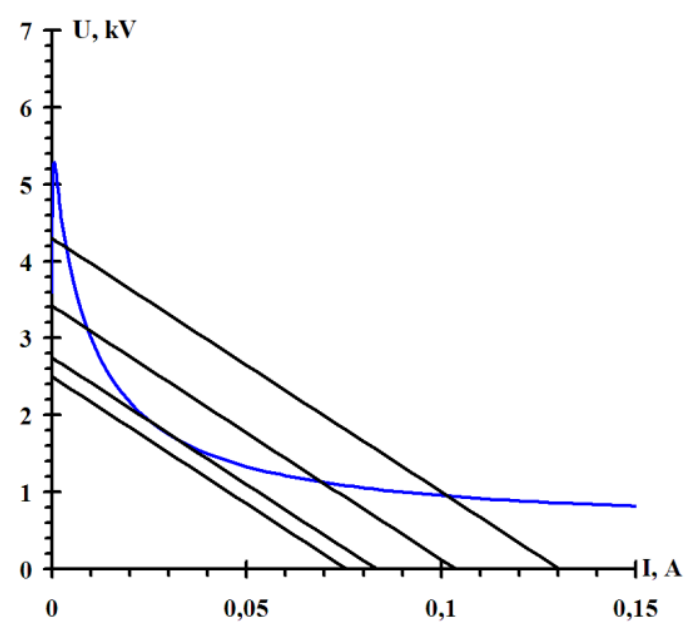

Fig. 8. The shift of load line from top to bottom relative to voltage-current characteristic during the decrease of PS output voltage

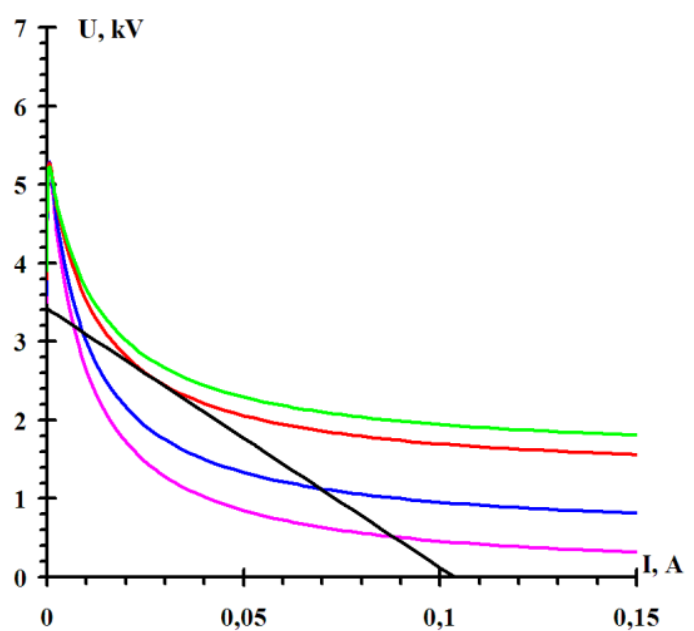

Fig. 9. The shift of voltage-current characteristic from bottom to top relative to load line due to increase of discharge channel length
Fig. 9 shows the shift of the voltage-current characteristic from the bottom to top relative to the load line due to the increase of the discharge channel length. The intersection between the load line and the voltagecurrent characteristic (see Fig. 9, pink) corresponds to the shortest discharge channel, the lowest voltage, and the highest current on the oscillograms. The intersection between the load line and the voltage-current characteristic (see Fig. 9, red) corresponds to the longest discharge channel, the highest voltage, and the lowest current on the oscillograms. If the length of the discharge channel increases further, the voltage-current characteristic (see Fig. 9, green) will be located higher than the load line and the discharge will extinguish. This is caused by the rise of the potential difference needed to support the discharge due to the increase of the discharge channel length.

Fig. 10 shows the dependence of the discharge channel length on the airflow into the discharge chamber. Fig. 10 shows that the length of the discharge channel depends on the airflow value. With the aperture diameter of $4 \mathrm{~mm}$, the discharge channel length grows with the increase of the airflow and reaches its maximum when the airflow rises to $101 \cdot \mathrm{min}^{-1}$. The further increase of the airflow leads to the decrease of the discharge channel length. This can be due to the change of the character of the airflow, which leads to the breaking of the discharge channel.

Fig. 11 shows the dependence of the electric field on the airflow into the discharge chamber. Fig. 11 shows that the electric field rises with the increase of the airflow into the discharge chamber.

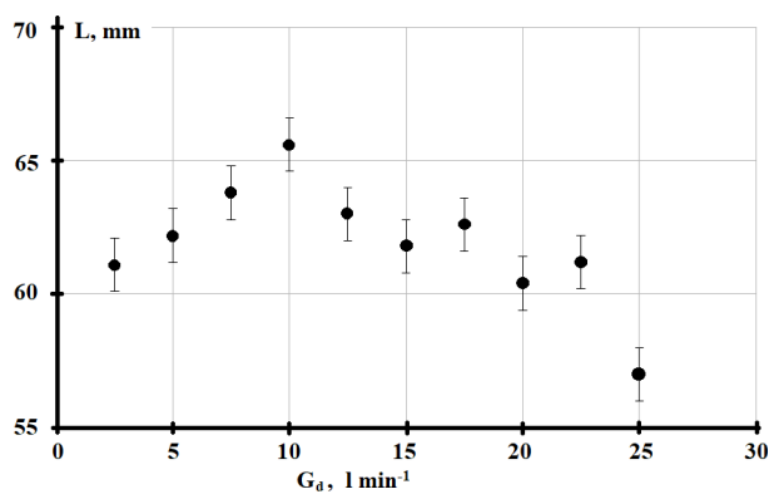

Fig. 10. Dependence of discharge channel length on airflow $G_{d}$ into the discharge chamber

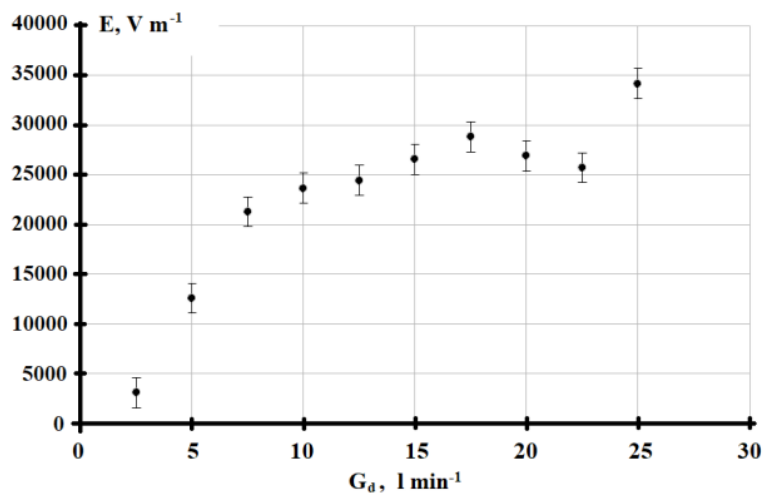

Fig. 11. Dependence of electric field on airflow into the discharge chamber 
This may be caused by the rise of the mean value of the voltage needed to support the discharge.

\section{CONCLUSIONS}

The length of the discharge channel depends on the value of the airflow. With the aperture $4 \mathrm{~mm}$ in diameter the discharge channel length initially increases and reaches the maximum at the $101 \cdot \mathrm{min}^{-1}$ airflow. Further increase of the airflow leads to the decrease of the discharge channel length. This may be connected to the change of the nature of the airflow, which leads to the breaking of the discharge channel at a shorter length.

The electric field rises with the increase of the airflow into the discharge chamber. This correlates with the change of the mean value of the voltage needed to support the discharge.

\section{ACKNOWLEDGEMENTS}

This work was supported in part by the Ministry of Education and Science of Ukraine, National Academy of Sciences of Ukraine, and the Taras Shevchenko National University of Kyiv.

\section{REFERENCES}

1. R. Sheldon. Green Chemistry, Catalysis and Valorization of Waste Biomass // Journal of Molecular Catalysis A: Chemical. 2016, v. 422, p. 3-12.

2. M. Crocker. Thermochemical conversion of biomass to liquid fuels and chemicals. RSC Publishing, 2010, $554 \mathrm{p}$.

3. A. Fridman. Plasma chemistry. Cambridge: Cambridge University Press, 2008, 1022 p.
4. V. Chernyak, O. Nedybaliuk, O. Tsymbaliuk, et al. Plasma chemistry for concept of sustainable development // Problems of Atomic Science and Technology. Series «Plasma Physics». 2017, № 1, p. 126-131.

5. D.L. Chernolutsky, V.V. Kolgan, V.Ya. Chernyak, et al. Study of the rotating gliding discharge at atmospheric pressure // Problems of Atomic Science and Technology. Series «Plasma Physics». 2014, № 6, p. $175-178$.

6. O.A. Nedybaliuk, V.Ya. Chernyak, I.I. Fedirchyk, et. el. Reforming of ethanol in hybrid plasma catalytic system // Problems of Atomic Science and Technology. Series «Plasma Electronics and New Methods of Acceleration». 2018, № 4, p. 164-167.

7. O.A. Nedybaliuk, V.Ya. Chernyak, V.V. Kolgan, et al. Plasma-catalytic reforming of liquid hydrocarbons // Problems of Atomic Science and Technology. Series «Plasma Physics». 2015, № 1, p. 235-238.

8. O.A. Nedybaliuk, V.Ya. Chernyak, I.I. Fedirchyk, et al. Plasma-catalytic reforming of biofuels and diesel fuel // IEEE Transactions on Plasma Science. 2017, v. 45, № 7, p. 1803-1811.

9. C.O. Laux, T.G. Spence, C.H. Kruger, R.N. Zare. Optical diagnostics of atmospheric pressure air plasma // Plasma Source Sci. Technol. 2003, № 2, p. 125-138. SPECAIR: http://www.specair-radiation.net

10. O.A. Nedybaliuk, I.I. Fedirchyk, V.Ya. Chernyak. Plasma-catalytic system with wide-aperture rotating gliding discharge // Problems of Atomic Science and Technology. Series «Plasma Physics». 2018, № 6, p. 214-217.

\section{ПЛАЗМЕННО-КАТАЛИТИЧЕСКАЯ СИСТЕМА С УЗКОАПЕРТУРНЫМ ВРАЩАТЕЛЬНЫМ СКОЛЬЗЯЩИМ РАЗРЯДОМ}

\section{О.А. Недыбалюк, П.В. Тищук, Т.А. Терещенко, И.И. Федирчик}

Представлены результаты исследования вращающегося скользящего разряда с узкой апертурой в потоке воздуха. Сопоставлены фотографии с осциллограммами напряжения вращающегося скользящего разряда с узкой апертурой. Из фотографий определены максимальная длина токового канала и ее зависимость от потока воздуха в разрядную камеру $\mathrm{G}_{\mathrm{d}}$. Из осциллограмм напряжения определена разница между максимальным и минимальным значениями напряжения $\Delta \mathrm{U}=\mathrm{U}_{\max }-\mathrm{U}_{\min }$. Построена зависимость электрического поля Е в положительном столбе от потока воздуха в разрядную камеру $\mathrm{G}_{\mathrm{d}}$. Измерены эмиссионные спектры плазмы вращающегося скользящего разряда с узкой апертурой и определено распределение колебательных $\mathrm{T}_{\mathrm{v}}$ и вращательных $\mathrm{T}_{\mathrm{r}}$ температур вдоль плазменного факела в реакционной камере.

\section{ПЛАЗМОВО-КАТАЛІТИЧНА СИСТЕМА 3 ВУЗЬКОАПЕРТУРНИМ ОБЕРТОВИМ КОВЗНИМ РОЗРЯДОМ}

\section{О.А. Недибалюк, П.В. Тищук, Т.А. Терещенко, І.І. Федірчик}

Представлено результати дослідження обертового ковзного розряду з вузькою апертурою в потоці повітря. Співставлено фотографії 3 осцилограмами напруги обертового ковзного розряду 3 вузькою апертурою. 3 фотографій визначено максимальну довжину струмового каналу та ії залежність від потоку повітря в розрядну камеру $\mathrm{G}_{\mathrm{d}}$. 3 осцилограм напруги визначено різницю між максимальним та мінімальним значеннями напруги $\Delta \mathrm{U}=\mathrm{U}_{\max }-\mathrm{U}_{\min }$. Побудовано залежність електричного поля Е в позитивному стовпі від потоку повітря в розрядну камеру $\mathrm{G}_{\mathrm{d}}$. Виміряно емісійні спектри плазми обертового ковзного розряду 3 вузькою апертурою та визначено розподіл коливних $\mathrm{T}_{\mathrm{v}}$ та обертових $\mathrm{T}_{\mathrm{r}}$ температур вздовж плазмового факела в реакційній камері. 